\title{
Innovation Strategy for Creating Successful Small and Medium Businesses
}

\section{Wihalminus Sombolayuk ${ }^{1}$, Ria Mardiana Yusup ${ }^{2}$ and Indrianty Sudirman ${ }^{3}$}

\author{
${ }^{1}$ Hasanuddin University, Indonesia \\ ${ }^{2}$ Hasanuddin University, Indonesia \\ ${ }^{3}$ Hasanuddin University, Indonesia
}

\begin{abstract}
This study aimed to explore the innovation strategy and the link between human capital, social capital, and financial capital as a factor that determines the success of small \& medium businesses. The approach is through the study of literature. The results show 1) human capital as in the dimensions of education, skills, experience, entrepreneurship determines the success of SMEs, especially in increasing product quantity and quality, sales and market share, capital and profit, customer satisfaction and competitiveness of SMEs. 2) Social Capital as in the dimensions of kinship, association, institutional, and professional networks determine the success of SMEs, especially in increasing product quantity and quality, sales and market share, capital and profit, customer satisfaction and competitiveness of SMEs. 3) Financial capital: as in the dimensions of access to financial institutions, sources of funding, investment and financial management determine innovation strategies such as the dimensions of the discovery and improvement of production methods / technologies, the creation of new products, product development and improvement, new market discoveries and market expansion. 4) Innovation strategies such as the dimensions of the discovery and improvement of production methods \& technologies, the creation of new products, product development and improvement, the discovery of new markets and market expansion determine the success of SMEs, especially in increasing product quantity and quality, sales and market share, capital and profit, customers satisfaction and competitiveness of SMEs
\end{abstract}

Keywords : Innovation Strategy, Creating of Small \& Medium Business Successful

\section{Introduction}

Small enterprise or small businesses or known in Indonesia as micro, small, and medium enterprises (SMEs) have a strategic role in national economic development. In addition to contributing to changes in economic growth and employment also plays a role in the distribution of results development results. SMEs businesses can make a significant contribution to the increase in gross domestic product, the amount, level of participation, and labor productivity, as well as the growth of Indonesian exports. Indonesia's economic crisis some time ago, where many large-scale businesses that stagnated even stopped their activities, the small business sector proved to be more resilient and even considered immune in dealing with the crisis.

Therefore, government policies must continue to be more conducive to the growth and development of businesses. The government needs to increase its role in empowering small businesses in addition to developing mutually beneficial business partnerships between large entrepreneurs and small entrepreneurs and improving the quality of its human resources. The development of small businesses in the future needs to combine local advantages (internal environment) and global market opportunities, which are synergized with the era of regional autonomy and free markets. In this case it is necessary to think on a global scale and act locally (think globally and act locally) in taking policies related to the development of small businesses Based on data from the Minister of Trade in 2014, when the economy was experiencing a decline, small businesses contributed positively to Indonesia's economy. Business contributions reached $6.3 \%$ of the Gross Domestic Product (GDP) which reached Rp. 104.73 trillion, although this figure has not reached the targeted number of reaching at least 9\% starting in 2015. Furthermore Jerusalem (2009), states that the presence of MSMEs can answer or as a solution to the challenges of basic short-term 
problems and medium in Indonesia, namely relatively low post-crisis economic growth (4.5\% per year), still high unemployment (9-10\%); (3) high level of poverty $(16.17 \%)$. In increasingly fierce business competition, strategic planning programs or the development of innovation must be carried out by every small business actor in order to be able to maintain business by improving superior performance. As a result of previous studies, the implementation of strategic planning in innovation is the main driver and influences business performance. (Viverita and Ariff, 2008).

During these successes SMEs are still facing various obstacles that must be addressed immediately in order to increase business productivity. Since the early days of its development, MSMEs have been predicted to face various challenges, one of which is the adoption of innovative technologies (Ministry of Tourism and Creative Economy, 2013). This statement is also supported by the Minister of Cooperatives and MSMEs (2014), that the weaknesses in many Indonesian industries are innovation strategies in innovation, which can increase productivity. Meanwhile, with the high potential of Indonesia, such as human resources and natural resources, without the adoption of technology that drives the latest innovations, industries in Indonesia will be difficult to compete in the global market.

The implementation of the innovation strategy will encourage the industry to create a standardized product at a lower cost in its operations to create efficiency (Viverita and Ariff, 2008). Furthermore, technological innovation is very instrumental in increasing global competitiveness, technological innovation can help industry to innovate, where every weakness can be reduced or even eliminated (Mohannak, 2007). The importance of researching about innovation strategies is supported by the fact that there are still many MSMEs that still rely on manual strategies without adopting technology that allows innovation to support business productivity (Minister of Cooperatives and SMEs, 2014). Factors that determine the success of a business including small businesses have been the topic of many academic debates. Researchers from various disciplines have agreed on the importance of identifying factors that influence the success of small businesses in designing an economic and investment policy such as job creation, increased wealth, and economic and social development (Autio, 2005; Omri and Ayadi-Frikha, 2014). The determinants of the success of small businesses have increasingly attracted the attention of policy makers, researchers, and practitioners, and have gained much attention theoretically. This attention is mainly focused on the relationship between the success of small businesses; with innovation and human capital, social capital, and financial capital (David, Fred R, 2011, Honig, 1998; Thornhill, 2006; Unger et al., 2011, Cooper et al., 1994).

In all countries of the world, small businesses are considered important elements for growth, job creation and social progress. Small businesses also become an important force for creating jobs, reducing poverty, activating competition, and increasing productivity and stimulating economic development.

He main objectives of this article are a) identifying direct relationships between human capital, social capital, financial capital and business success, b) identifying direct relationships between human capital, social capital, financial capital with innovation strategies, c) identifying the direct relationship between innovation strategies with business success, and d) identify mediating relationships between human capital, social capital, financial capital and business success through innovation strategies.

Resources Based View (RBV). Organizations or in this study called SMEs are a collection of resources, inputs with unique capabilities, which can provide support in implementing a strategy to face competition and achieve company goals optimally. This view is then known as resource-based view (RBV).

Penrose (1959) is a scientist who conceptualizes a company as a collection of previous resources Wernetfelt (1984) states the first time the origins of RBV in an article entitled A Resource-based view of the firm and distinctive competencies, based on writing Penrose about the definition of the firm as a system of productive resources. But the most influential theory is the RBV which was presented by Barney (1991), entitled The Resources Based View of The Firm. 
There are two assumptions attached to RBV, namely resource heterogeneity and immobility resources. Resource heterogeneity (also called resource diversity) refers to whether a company has resources or capabilities that are also owned by other companies that are competitors? so that these resources are considered not to be a competitive advantage. While immobility resources refer to a resource that is difficult to obtain by competitors, to obtain or use these resources requires very high costs.

According to Barney (1991) "Resources that are valuable, rare, affordable, and non-substitution lead to the achievement of sustainable competitive advantage that cannot be easily duplicated by competitors".

Human Capital. This concept basically assumes that humans are a form of capital or capital as other forms of capital, such as machinery, technology, land, money and material.

However, humans as human capital is reflected in the form of human resource competencies such as level of education, knowledge, experience, ideas, creativity, skills, and work productivity. Unlike other forms of capital that are only treated as tools. This Human Capital can invest itself through various forms of investment in human resources, including formal education, informal education and work experience and skills.

human capital theory assumes that knowledge brings greater cognitive skills, so human capital is considered to have the potential to increase productivity and efficiency (Becker, 1964).

Social Capital. Social capital is a number of actual or virtual resources that develop in a person or group of people because of their ability to possess or control which can last a long time and is a productive asset and is built through investment in social relations, which requires time, effort and money to accumulate it.

Woolcock (1998) defines social capital as "the information, trust, and norms of reciprocity inhering in one 's social networks", (Ancok, 2002). Cohen and Prusak argued that "Social capital consists of the stock of active connections among people: the trust, mutual understanding and shared values and behaviors that enable members of human networks and communities and make cooperative action possible. Social capital is a collection of active relationships between people: trust, mutual understanding and shared values and behaviors that bind members in a network and community that enables cooperation (Ancok 2002). In line with Fukuyama's opinion, Bowles \& Gintis defines social capital as follows: Generally, social capital refers to trust, concerned for one's associates, a willingness to live by the community, and those who do not. (Ancok, 2002)

Stone and Hughes,2002: Carrion, Izqierdo, \& Cillian, 2017) measure social capital, to suggest measurement of the network dimension of relationships as follows:

1) Personal relationships, namely groups of people you often contact in your personal environment, such as relatives, friends, neighbors, or acquaintances or with whom you share informal social activities. 2) Associative relationships, which are groups of people who belong to the same association with you and people you often contact. These are a kind of association such as civil rights groups, voluntary associations, cultural associations, sports associations, political parties, trade unions, women's associations, neighboring associations, professional associations, and religious groups. 3) Professional relationships, namely groups of people you often contact in professional circles (both in your current business and business or previous work), such as professional partners, workers in companies, partners, suppliers, distributors, clients, or your coworkers. 4) Institutional relations, namely people who often maintain direct contacts and public institutions, such as public services, police, politicians, public sector workers, or representatives of local, national, and private institutions, such as large companies and banks, institutions, media, and so on

Financial Capital. Financial capital is defined as the ability to obtain financial resources, build and maintain real capital, which allows companies to play a productive role in the economy (Fama and Miller, 1972).

Fritsch and Meschede (2001) have found that the availability of financial resources is a major factor in the innovation strategy of small businesses. Therefore, financial capital helps companies 
implement new strategies and innovation projects that may have limited resources (Cooper et al, 1994).

Concept of Innovation Strategy. The innovation strategy of a manufacturing company can serve as a guide and guidance for executing executives in four ways, namely as follows (Zahra and Das, 1993, Afuah, 1998).

a. Product, process or method strategy is a strategy used as a way of dealing with competition, thus there is a relationship of company activities with the company's innovation strategy (for example with the company's long-term planning).

b. The innovation strategy in the company helps the executive in allocating limited resources by choosing projects that can improve the company's capabilities and competencies. Thus, innovation helps to differentiate the company's products on the market, give effect to negotiations with suppliers and distract from company competition.

c. This strategy forces the executive to explain the focus and source of future manufacturing innovations by considering the company's strategy, industry conditions, internal capabilities, resources, strengths and weaknesses. This will help ensure that the innovation effort is in accordance with the desire to achieve success.

d. Innovation strategies can also help companies to clarify their competitive advantage through different products and create value for consumers (creating value to customer). If a new product or process is different from other existing products that make the product unique, it will be very difficult for competitors to replicate (Jajja, et al. 2017). Companies can use these innovation products to protect existing markets or market to new niche markets, thereby increasing financial performance that is superior to competitors.

The Concept of Success. Financial business success refers to the success measured in terms of financial indicators. More specifically, measuring success or failure with a variety of financial indicators, such as earnings, sales turnover, stock prices, income, etc., determines financial business success (Garrigos-Simon \& Marques, 2004; Grant, 1991).

Business success in non-financial aspects refers to situations where success with other than, such as an increase in the number of employees, efficiency, reputation, perception, market share, etc. (Tseng, 2010) has considered number of employees, future strategies, and non-qualitative indicators such as goodwill and company reputation create branding through which customers.

Research conducted by Covin and Slevin (1989) measures the company's financial performance by asking each respondent based on the importance level

The Concept of Small and Medium Enterprises. According to Law No. 20 of 2008 concerning micro, small and medium enterprises or abbreviated as UKM:

1) Micro Business Criteria are as follows:

a) Have a maximum net asset of Rp. 50,000,000 (fifty million rupiahs) not including land and building of business premises;

b) Have annual sales results of a maximum of Rp. 300,000,000.00 (three hundred million rupiahs).

2) Small Business Criteria are as follows:

a) Having a net worth of more than Rp. 50,000,000.00 (fifty million rupiahs) up to a maximum of Rp. 500,000,000.00 (five hundred million rupiahs) not including land and business premises;

b) Having annual sales results of more than Rp. 300,000,000.00 (three hundred million rupiahs) up to a maximum of Rp. 2,500,000,000.00 (two billion five hundred million rupiahs).

(3) Medium Business Criteria are as follows:

a) Having a net worth of more than Rp. 500,000,000.00 (five hundred million rupiahs) up to a maximum of Rp. 10,000,000,000.00 (ten billion rupiahs) not including land and building of business premises; 
b) Has annual sales results of more than Rp.2,500,000,000.00 (two billion five hundred million rupiahs) up to a maximum of Rp.50,000,000,000.00 (fifty billion rupiahs).

\section{Research Methodology}

To answer the problem and achieve the purpose of writing this article, the discussion method used is a literature study method or literature study by exploring various questions, concepts and results of previous research related to this article.

The method of discussion of this article is based on the input model (human, social, and financial capital), strategy (innovation), and output (success). To achieve the study of the problem, it is done systematically as follows: a) direct relationship between human capital, social capital, financial capital with innovation strategy, b) direct relationship between human capital, social capital, financial capital and business success, c) relationship directly between innovation strategies and business success, and d) mediating relationships between human capital, social capital, financial capital and business success through innovation strategies.

\section{Result and Discussion}

Relationship of Human Capital with Innovation Strategies. Entrepreneurship in humans is usually regarded as an innovation process, activity, or strategy that has an important role in developing a business. Innovation Strategy is a process that starts with an idea, the results of the development of an invention, the result of the introduction of a new product or service (Edwards and Gordon, 1984). Corporate innovation strategies can be initiated by individuals or organizations that reflect entrepreneurial orientation (Lumpkin and Dess, 1996). The concept that there is a relationship between entrepreneurship and innovation strategies generally comes from the work of Schumpeter (1934,).

Schumpeter is interested in studying the importance of innovation strategies. A similar perspective by Miles and Snow (1978) states that an entrepreneur innovates through discovery on the market. Drucker (1985) considers entrepreneurs who are innovators who find innovation success, learn and apply the principles that enable innovation to succeed.

Research into human capital, innovation strategies have become an important domain, especially in the fields of economics and management science (Manolova et al., 2008; Manikas and Terry, 2010). The importance of human capital as a determinant of innovation strategies has been the object of several theoretical and empirical studies in the past few years. Education, training and knowledge of entrepreneurs play an important role in providing the resources needed to create and develop business (Donckels and Frohlich, 1991).

Thus, efforts to understand the innovation strategy of small businesses must be done by examining the characteristics of the founders of the company. Likewise, related to small enterprise innovation strategies on the elements of education, knowledge and skills (Mahemba and De Bruijn, 2003; Lin, 1998) and investments in training and education (Baumol, 2004), theoretically this view verifies the second step in modeling mediation of innovation strategies that involve a positive relationship between innovation strategies (mediation variables), human capital (independent variables

David, (2011) explained that the Innovation strategy is a complex process, and human capital is an important component of this process. Human capital relations with innovation strategies have two different aspects, the process of distribution and use of innovation, and the creation of new products. Capabilities and competencies such as knowledge, experience and work skills that allow access to a wider range of opportunities for innovation (Moschieri and Mair, 2011; Omri and Frikha, 2012; Andries and Czarnitzki, 2014). The higher the level of education of employees, the higher the innovation of work (Ahmad et al, 2011; Agostini, 2016). So, in this case there is a positive relationship between the level of education of employees and (Gimeno, et al, 1997; Davidsson and Honig, 2003; Parihar et al, 2013; Peters et al, 2017). 
Angela Baron, (2011) asserts that the size of human capital can be measured by competencies such as the level of education, practice, and skills possessed by employees who can be converted into intellectual capital in the form of products and services that provide market value. Likewise, who argues that employees have knowledge and skills acquired through education and training activities that contribute to the quality of human capital in designing and implementing innovation strategies (Cantner 2010)

The innovation ability of an organization according to Martín-de Castro, Delgado-Verde, NavasLópez \& Cruz-González (2013) depends on intellectual and / or organizational knowledge assets and their ability to use these assets. Knowledge assets enable the formation of Innovation, which is a process that starts with an idea, results of development of findings, results of the introduction of new products or services (Hunt and Ortiz-Hunt, 2017).

Baldwin and Johnson (1995) explain that human capital is an important part of small and medium business innovation strategies. In fact, companies that are managed by individuals with limited experience or who lack formal education have proven to be less innovative (Hausman, 2005). Lack of skills causes small companies cannot change or oversee the superiority of knowledge to new products and services Urbach et al., (2011). Knowledge (Thornhill, 2006) and education (Baumol, 2004) are important elements for innovation strategies. Hage and Aiken (1970) stated that through knowledge, entrepreneurs can increase business success. Knowledge plays a basic role in carrying out innovation strategies and the use of new technologies, as well as individual training to contribute to learning internally and generate new ideas (Damanpour, 1991; Galende and Fuente, 2003; Ahmad et al, 2010; Unger et al, 2011).

According to Koellinger (2008), the educational background of managers, business owners, and employees proved to be important factors in small company innovation. By examining 845 innovative companies in Canada in the manufacturing sector, Thornhill (2006) concluded that there was a positive relationship between knowledge based on individual experience and training in innovation activities in entrepreneurship. Human capital is considered a determinant of innovation. Innovation is the result of the creativity of employees in an organization shown to customers and provides added value. Human capabilities possessed by an organization can encourage innovation (Huggin et al, 2012; Martin, 2012; Valaei et al. 2017). So, the factor of human capital, which consists of knowledge, skills, experience and educational background obtained from the process of education, training and development is an indispensable element in the formulation of strategies.

Relationship of Social Capital with Innovation Strategies. Social capital is the basis for the formation of synergy in carrying out organizational tasks that will determine innovation (Huang et al, 2010; Acquaah and Appiah-Nkrumah, 2011; Lightfoot and Gebauer, 2011). The broader the relationship of a person and the wider social networking (social networking) the higher a person's value (Brown, 2010; Ahmad et al, 2011; Cerne et al, 2013). Social capital embedded in managerial relations is seen as beneficial when (1) high environmental uncertainty (D'Alvano and Hidalgo, 2012), (2) imperfect market competition Cosgun and Dogerlioglu (2012).Social capital is the basis for the formation of synergy in carrying out the tasks of an organization that will get greater work results, when compared to working individually. The ability to build social networks is what is called social capital. The broader one's relationship and the wider social networking network, the higher a person's value.

Social capital that is formed in a network of social relations bound by ownership of information (O'Connor, 2012; Ng and Rieple, 2014), trust (Nonino, 2013), mutual understanding, and shared values, and mutual support can drive innovation (Luca and Presuti, 2010; Verbees and Meulenbderg, 2014; Meyer, 2014). Social capital will be stronger if a community or organization has a network of cooperative relationships, either internally within a community or organization, or a cooperative relationship that is between communities or organizations (Bizzi and Langley, 2012; Brem et al, 2016; Jussila et al, 2016). Synergistic cooperation networks will provide benefits to innovation.

Social capital not only affects individuals but also significantly influences the way of managing, developing, maintaining and innovating sustainability and organizational success (Jack, 2010; Omri 
and Frikha 2012; Omri and Ayadi-Frikha 2014). The role of social capital can be used to understand entrepreneurial behavior in the initial phase of the company (Aldrich and Zimmer, 1986; Nashbandi, 2016; Moretti, 2017).

Social capital helps entrepreneurs obtain a moral support, opportunities to start operations, and the ability to face consolidation difficulties in the company (Adler and Kwon, 2002). Other researchers emphasize the importance of social capital in the process of growth and capacity of corporate innovation (Hausman, 2005; Landry et al. 2002). Theoretical support for the role of social networks to enhance innovation can be found in the literature of organizational studies Bustinza et al., 2017). Noteboom (1999) claims that social networking can help in innovation, because to be innovative, companies need outside sources of cognition and competence to complement their own needs. This helps exchange knowledge and learning (Praise and Casher 2003). Synergism occurs in collective learning because of the complementarity of resources and has the greatest potential to produce innovations that generate market benefits (Ritala and Hurmelinna-Laukkanen, 2013).

Research on the impact of the socialization process that usually occurs within social networks indicates a strong relationship between socialization and willingness to share information (Lee, 2017), engaging in joint problem solving, adapting to unexpected changes, and restraining from the use of power (Mahama 2006), all of which can encourage innovation (Bayne et al., 2017).

Empirical evidence about how social networks between organizations improve innovation and the application of innovation in organizations are strongly determined by network relationships between organizations (Bagno et al., 2017).

Although there are still few empirical studies on the relationship between social capital and innovation (Jack et al, 2010), which focus on the influence of social capital on corporate innovation activities, this relationship has been the subject of debate, especially among network theorists. social (Parra-Requena et al, 2013). The researchers argue that there are positive effects of social networks on the ability to innovate as found by Adler and Kwon (2002).

Hsieh and Tsai (2007) found that social capital is positively related to strategies for introducing innovation products in high-tech companies. Lee, et al (2010) have emphasized the effectiveness of networks as a way that might facilitate the capacity of innovation in small and medium enterprises. Landry, et al. (2002) based on a survey of 440 industrial companies in Montreal show the importance of social capital in a company's innovation strategy. In his research found that social capital and especially social networks of entrepreneurs can play an important role in the company's innovation strategy. Building a business network with business consultants, accountants, customers and among other stakeholders has a positive effect on their business (Jack, 2010; Stephens, 2013).

Relationship of Financial Capital with Innovation Strategies. Financial capital is defined as the ability to obtain financial resources, build, and maintain real capital, which allows companies to play a productive role in economic value (Fama and Miller, 1972). Access to financial capital is always important to start and grow a business, especially when companies are still small and when companies grow.

In Indonesia, small businesses are often characterized by weak innovation capabilities (Sulistianto, 2011). There are several obstacles to the development of small business innovation (Prajogo, 2006; Tambunan, 2008, World Bank, 2015). Most have limited financial capacity (Hausman, 2005; Tambunan, 2008; Prajogo, 2011; Rahman, et al, 2015).

Therefore, additional aspects of small-scale business capital in Indonesia as well as the amount of capital limits in order to pay for research and development or investments related to innovation are always faced with the constraints of accessing external financing. Schumpeter emphasizes the ability of large companies to invest in new processes to reduce costs and initiate a development and development program that leads to the introduction of new products.

Fritsch and Meschede (2001) have found that the availability of financial resources is a major factor in the innovation strategy of small businesses. Therefore, financial capital helps companies implement new strategies and innovation projects that may have limited resources (Cooper et al, 
1994). Austaralia's government policy to provide additional capital through credit policy for small businesses encourages small companies to introduce new technologies, implement new product innovations, get bigger funds, and seek access to professional consultations. (Dong Xiang, et al. 2017).

Ownership of financial capital has a direct effect on innovation (Stam, et al, 2014). Direct effects include the ability to carry out more ambitious innovation strategies and meet funding demands. In the case of indirect effects, financial capital accumulation can encourage better training and broader planning in innovation, which ultimately has a positive effect on business success. Orser (2000) in research has revealed that a lack of financial capital is a major obstacle to accessing finance for the success of small businesses rather than other businesses that have adequate financial capital. Companies that are unable to secure external capital may be more susceptible to the vicious changes faced by small companies in general (Brown et al., 2005; Prajogo, 2011).

Relationship of Human Capital with SME Success. Initially, human capital theory was developed to estimate employee income distribution based on investment in human capital and explain that people try to get compensation because of investments in human capital and try to maximize the economic benefits of human resources owned by small businesses. (Becker, 1964). This theory, which is often used by entrepreneurial researchers and encourages the emergence of various studies on entrepreneurship. (Unger, 2011).

The idea that the success of a company is influenced by human capital is not new (Penrose, 1959), the most important stock of a company is human capital, the more successful the business, the greater the competitive advantage over human resources (Brown, 2005). involved in business, then investing in human capital allows companies to develop rather than individuals who do not invest or are not investing.

Entrepreneurship literature contains several arguments about how human capital improves business success. First, human capital generally makes it easier for company owners to find and utilize business opportunities that are not seen by others (Liao, 2011; Pereira et al, 2018). Second, human capital is positively related to planning and risk strategies, which in turn affect the success of the company (Acquaah and Eshun, 2010; Perry-Smith and Mannucci, 2017). Third, knowledge derived from human capital can be used to increase other resources, such as finance, physical capital, and nonphysical (Brush, 2001; Baptista et al., 2013; Audretsch et al., 2014).

Angela Baron, (2011) asserts that measures of human capital can be measured by competencies such as education level, practice, skills possessed by employees can be converted into intellectual capital in the form of products and services that provide market value. Similarly, the management skills and entrepreneurial experiences that exist in humans and are used in companies positively affect the economic performance of new companies (Gimeno, et al. 1997), authors that determine the success of a company have been the object of debate among academics (Atherton and Smallbone, 2010; Lee et al., 2010; Lans et al., 2011; Huang, 2016; Hong et al. 2018 ) Some researchers who are interested in finding the relationship between entrepreneurship and success emphasize the importance of human capital or entrepreneurs (entrepreneurs) to achieve business success (Huang, 2016). Human capital is considered as a determining factor in achieving business success. Thus, knowledge, work skills, management experience and entrepreneurial experience are positively related to performance (Cooper, et al, 1994; Gimeno, et al., 1997; Wensley et al., 2011; Xu, 2015).

Quality human beings will ensure the continuity of a company's growth (Carsrud and Brnnback, 2011; Damanpour and Aravind, 2011; Knörr, 2011; Dayan et al., 2016). Several studies have found that human capital is an important factor for organizational success (Gimeno, et al, 1997; Gúndogdu, 2012; Hall et al., 2012; Naqshbandi, 2016). Human quality makes it easier for companies to make innovative breakthroughs.

Based on an analysis of internal and external conditions, humans produce ideas that can help organizations gain competitive advantage (Lee et al, 2011) and can deceive their competitors, at least for a certain period. Furthermore, human capital consists of individual attributes as formal education, 
work knowledge and experience, and the presence of partners who may provide additional expertise. This type of capital is considered unique because knowledge cannot be taken away from individuals as tangible assets. The presence of human capital has an impact on the quality of business behavior. As a result, human capital in the form of education, knowledge, experience and work skills provided by entrepreneurs are the main determinants to ensure business success (Cooper et al, 1994; Honig, 2001).

Relationship of Social Capital with SME Success. Several studies show that entrepreneurs who have higher levels or degrees have potential social capital to create high growth and profitability of the company (Nashbandi, 2016; Peters et al., 2017). Social capital, in the form of resources embedded in the private network of entrepreneurs, is very important for improving the performance of small businesses (Chittithaworn et al, 2013; Baden-Fuller and Haefliger, 2013). For example, social network connections called social capital allow entrepreneurs to identify new business opportunities, obtain resources at costs that are below market prices, and increase legitimacy through external stakeholders (Berrou and Combernous, 2011; Boso et al., 2011; Stam, et al 2014).

Among the studies conducted by Blumberg and Pfann (1999), and Honig (1998) confirm the important role of social capital, especially in the influence of entrepreneur's social capital on the success of companies, especially small-sized companies. This approach shows that social capital is an important element of small business success (Huizingh, 2011; Jämsä et al, 2011; Omri et al, 2015). Teece (2005) states that the communication process in social networks is an important competency to achieve company success. Social capital includes the context of the existence of relationships, interpersonal beliefs, and behavioral norms, relationships between individuals, which ensures conditions for organizational development and knowledge (Bouncken, 2011). The network of relations between entrepreneurs, for example, becomes an asset because they have a competitive advantage by providing access to, processes and distribution of information and resources (Bagno et al, 2017). Several studies show that entrepreneurs who have a higher level have more social capital for high growth and profitability There are many areas of social capital, in the form of resources in private networks, which are very important for improving the performance of small businesses.

Social capital not only affects individuals but also significantly influences the way of managing, developing, maintaining and succeeding and sustaining the organization (Jack, 2010; Omri and Frikha 2012; Omri and Ayadi-Frikha 2014). The role of social capital is not only studied in the discipline of sociology (Granovetter, 1985), but is used to understand entrepreneurial behavior in the initial phase of the company (Aldrich and Zimmer, 1986),

Among the studies conducted by Blumberg at, al (1999), and Honig (1998) confirm the important role of social capital, especially in the influence of entrepreneur social capital on the success of companies, especially small-sized companies.

This approach shows that social capital is an important element of small business success. Social capital helps entrepreneurs obtain the needed moral support, opportunities to start operations, and the ability to face consolidation difficulties in the company (Adler and Kwon, 2002). Other researchers emphasize the importance of social capital in the process of growth and capacity of corporate innovation (Hausman, 2005; Landry et al. 2002). and social capital determine business success (Brancati, 2015).

Relationship of Financial Capital with SME Success. Cooper, et al. (1994) have found the positive effects of financial capital early on business growth and success. The form of ownership of financial capital has a direct effect on entrepreneurial success (Cooper, et al, 1994). Direct effects include the ability to carry out more ambitious strategies and meet funding demands. In the case of indirect effects, financial capital accumulation can encourage better training and broader planning, which ultimately has a positive effect on business success.

Orser (2000) in research has revealed that a lack of financial capital is a major obstacle to accessing finance for the success of small businesses rather than other businesses that have adequate financial capital. Companies that are not capable of securing external capital may be more vulnerable to the 
ripple changes faced by small companies in general. Furthermore, studies show that financial capital (Coleman, 2007; Unger et al., 2011; Baptista et al., 2013). necessary for the creation of success, and the survival of small businesses.

Relationship between Innovation Strategies with SME Success. Several studies have shown the relationship between innovation strategies and the success of small and medium enterprises (Rauch and Frese, 2000). The results of research conducted by Zahra, et al (1993) and some opinions of experts who suggested that the dimensions of innovation strategies will affect the company's financial performance.

Product innovation activities in the context of product development in manufacturing companies that are associated with company performance are important things that must be considered to face competition (Andersen, 2011). Product innovation includes the creation, selection and development or improvement of products, processes and technology (Zahra, et al, 1993; Tapsel and Woods, 2010) These innovations can enhance the company's global position and help them achieve the status of producing world-class quality goods (Birkinshaw et al., 2011; Suliyanto, 2011; Brentani and Reid, 2012). By using new technology, the creation and introduction or marketing of new products and adopting innovative production processes, companies can effectively solve competition problems.

Corporate innovation strategies can be initiated by individuals or organizations that reflect entrepreneurial orientation (Vega and Brown, 2013). Previous management experience and skills and entrepreneurial experience positively influence the economic performance of new companies. The study of this relationship finds that there is a positive relationship between innovation and success strategies (Cefis and Marsili, 2006; Heunks, 1998; Thornhill, 2006; Astrachan, 2010). Business success can be measured by many different variables (Ravesteyn and Batenberg, 2010). For example, in a survey of 845 Canadian manufacturing companies, Thornhill (2006) measured success by increasing income and detected that there was a positive relationship between innovation and company success. In this study success is measured by the average monthly profit (Thornhill, 2006). Presentation on RBV or RBT, which has been stated previously under companies with greater innovation capabilities and supported by ownership of resources such as human capital, social capital and financial capital, organizational culture, and government policies, which have competing competencies and capabilities. quickly achieving better responses from the environment, more easily obtaining the skills needed to improve consolidating competitive advantage and the sustainability of the organization to achieve success. (Calantone, ddk, 2002).

Schumpeter and Drucker (1998) argue that the ability to innovate is one of the core characteristics of an entrepreneur. Heunks clear that that strategy innovation is more appropriately used by small and medium enterprises because it seems more useful to use to maintain market share, production at low cost and flexibility of its business.

Innovation-oriented companies must develop strategies formally and comprehensively. This strategy explains the company's goals in innovating by explaining the results (what is developed) and the way (how to achieve them). The innovation strategy of a manufacturing company can function as a guide and a handle.

Hamel (1994) says that innovation is characterized by traditional management principles, processes, and practices or departs from a form of organizational culture that significantly changes the way management works, which reflects the extent to which new knowledge is embedded in the company's organization.

Baron and Keney (1986) stated that in order to achieve sustainable competitive advantage then a business strategy must be designed to involve or use all resources that have the competence and capability towards achieving the company's success goals in the context of sustainable competitive advantage through the support of innovation processes or strategies (Omri and Firkha et al, 2012; 2014).

Research conducted by Covin (1994) uses only one strategy classification, namely product or service innovation strategy. Baron \& Keney's (1986) study continued with Omri and Firkha's research (2012; 
2014) has empirically succeeded in constructing a mediational relationship model between resources such as human capital, social capital and financial capital with success business with the SME growth dimension through the process innovation. In conditions and characteristics (SMEs) in Indonesia, especially in the city of Makassar which is the object of this research needs to be considered to examine not only the mediating or human capital effects, social capital, financial capital, but also add to the culture variables, government policies on business success through strategy innovation.

Relationship between Human Capital with Success through Innovation Strategies. Efforts to understand the innovation strategies of small businesses must be done by examining the characteristics of the founders of the company (Ansari et al, 2012; Mitchelmore and Rowley, 2013). Likewise, related to small enterprise innovation strategies on the level of education, knowledge and skills (Mahemba and De Bruijn, 2003; Lin, 1998) and investment in training and education (Baumol, 2004: Rip, 2012). According to Coleman (1988) human capital functions not only as a single identity but multiple identities, that is, first social capital includes social structures and both social capitals facilitate certain actions in the structure. Social capital has three forms, namely first the structure of obligations, expectations and trust, the second network of information is the norms and effective sanctions.

Human capital determines the success or failure of a company to innovate (Ritala, 2012) which leads to the success of the company (Atherton, 2008; Sousa and Aspinwall, 2010; Stam et al, 2014). Research result . Omri and Firkha et al. (2012: 2014) about mediational relationships or influences between resources such as human capital and business success with the growth dimension of SMEs through an innovation process that empirically confirms that there is a power relation such as human capital with small business success through the innovation process.

Relationship between Social Capital with Success through Innovation Strategies. Teece (2005) states that the communication process in social networks is an important competency to achieve company success. Social capital includes the context of the existence of relationships, interpersonal beliefs, and behavioral norms, relationships between individuals, which ensures conditions for organizational development and knowledge. Several studies show that entrepreneurs who have higher levels have more potential social capital to create high growth and profitability of the company (Capó-Vicedo et al, 2011; Smith and Bagchi-Sen, 2012). There is broad agreement that social capital, in the form of resources embedded in the private network of entrepreneurs, is essential for improving the performance of small. For example, social network connections called social capital allow entrepreneurs to identify new business opportunities, obtain resources at costs that are below market prices, and increase legitimacy through external stakeholders (Stam, et al 2014).

Among the studies conducted by Blumberg and Pfann (1999), and Honig (1998) confirm the important role of social capital, especially in the influence of entrepreneur social capital on the success of companies, especially small-sized companies. This approach shows that social capital is an important element of small business success. Social capital helps entrepreneurs obtain the needed moral support, opportunities to start operations, and the ability to face consolidation difficulties in the company (Adler and Kwon, 2002). Other researchers emphasize the importance of social capital in the process of growth and capacity of corporate innovation (Hausman, 2005; Landry et al. 2002)

Although there are still few empirical studies of the relationship between social capital and innovation, which are focused on the influence of social capital on corporate innovation activities, this relationship has been the subject of debate, especially among theorists on social networks. The researchers argue that there are positive effects on innovations as found by Adler and Kwon (2002), Tsai and Ghoshal (1998. Several authors, such as Calantone, et al (2002) suggest that intraorganizational knowledge can influence the capacity of corporate innovation by promoting creativity and inspiration for new knowledge and ideas. Hsieh and Tsai (2007) found that social capital is positively related to strategies for introducing innovation products in high-tech companies. Lee, et al (2010) have emphasized the effectiveness of networks as a way that might facilitate the capacity of innovation in small and medium enterprises.Landry, et al. (2002) based on a survey of 440 industrial 
companies in Montreal show the importance of social capital in a company's innovation strategy. In his research it was found that social capital, and especially the social network of entrepreneurs can play an important role in the company's innovation strategy. Building a business network with business consultants, accountants, and customers, among other stakeholders, has a positive effect on their business (Stephens, 2013).

Research of Omri and Firkha et al. (2012: 2014) about mediational relationships or influences between resources such as social capital and business success with the growth dimension of SMEs through an innovation process that empirically confirms that there are power relations such as human capital with small business success through the innovation process.

$\mathrm{n}$ Indonesia small businesses are often characterized by weak innovation capabilities (Ekoputri et al, 2007; Tambunan, 2010). There are several obstacles to the development of small business innovation. Most have limited financial capacity (Hausman, 2005).

Therefore, additional aspects of small-scale business capital in Indonesia as well as the amount of capital limits in order to pay for research and development or investments related to innovation are always faced with the constraints of accessing external financing. Schumpeter emphasizes the ability of large companies to invest in new processes to reduce costs and initiate a development and development program that leads to the introduction of new products.

Ritsch and Meschede (2001) have found that the availability of financial resources is a major factor in the innovation strategy of small businesses. Therefore, financial capital helps companies implement new strategies and innovation projects that may have limited resources (Cooper et al, 1994; Stam et al, 2014).

Orser (2000) in his research has found that a lack of financial capital is a major obstacle to accessing finance for small business success than other businesses that have adequate financial capital. Companies that are not able to secure financial capital are more susceptible to the vicious changes faced by small companies in general. Financial capital allows a company to innovate and succeed. Several studies have shown a positive role that financial capital plays a role in the success of small businesses (Price et al, 2013). For example, Honig (1998) found that there was a positive relationship between financial capital and small business success, as measured by the average monthly profit. Similarly, Cooper, et al, 1994) have found the positive effects of financial capital early on business growth and success. The study shows that the financial capital of entrepreneurs plays a positive role in the success of small businesses.

\section{Conclusion}

Based on the above discussion, you can formulate several propositions as a conclusion as follows:

1. Human capital such as the dimensions of education, skills, experience, entrepreneurship determines the success of SMEs, especially in increasing product quantity and quality, sales and market share, capital and profit, customer satisfaction and competitiveness of SMEs.

2. Social Capital such as the dimensions of kinship, association, institutional and professional networks determines the success of SMEs, especially in increasing product quantity and quality, sales and market share, capital and profit, customer satisfaction and competitiveness of SMEs

3. Financial capital such as the dimensions of access to financial institutions, sources of funding, investment and financial management determine innovation strategies such as the dimensions of the discovery and improvement of production methods / technologies, the creation of new products, product development and improvement, new market discoveries and market expansion.

4. Innovation strategies such as the dimensions of the discovery and improvement of production methods \& technologies, the creation of new products, product development and improvement, the discovery of new markets and market expansion determine the success of SMEs, especially in increasing product quantity and quality, sales and market share, capital and profit, customers satisfaction and competitiveness of SMEs 
The limitation of this article lies in literature review methods from other countries which of course differ in characteristics from small and medium-sized enterprises in Indonesia.

To prove the prepositions produced from the above studies, it is expected that the next researcher will test the prepositions above with a quantitative approach.

\section{References}

Acquaah, M. and Appiah-Nkrumah, J. 2011. Firm-specific managerial experience and the social capital-performance relationship in a sub-Saharan African transition economy. Journal of African Business, 12(1), pp. 8-30.

Acquaah, M. and Eshun, J.P. 2010. A longitudinal analysis of the moderated effects of networking relationships on organizational performance in a sub-Saharan African economy. Human Relations, 63(5), pp. 667-700

Adler, P.S. and Kwon, S. (2002), Social Capital: Prospects for A New Concept, Academy of Management Review, Vol. 27 No. 1, pp. 17-40.

Afuah, A. 2014. Business Model Innovation: Concepts, Analysis, and Cases. New York: Routledge.

Agostini, L. 2016. Organizational and managerial activities in the development process of successful SMEmarketing networks. European Management Review, 13(2), pp. 91-106..

Ahmad, N.H., Wilson, C. and Kummerow, L. 2011. Assessing the dimensionality of business success: the perspectives of Malaysian SME owner-managers. Journal of Asia-Pacific Business, 12(3), pp. 207-224.

Aldrich, H. and Zimmer, C. (1986), Entrepreneurship through Social Networks, in Sexton.

Anderson, N., Potocnik, K. and Zhou, J. 2014. Innovation and creativity in organizations a state-ofthe-science review, prospective commentary, and guiding framework. Journal of Management, 40(5), pp. 1297-1333

Andrea \& Lantub Crestofel Donald, 2015. Servant Leadership and Human Capital Management: Case Study in Citibank Indonesia, Procedia - Social and Behavioral Sciences 169 ( 2015 ) 303 - 311, Published by Elsevier Ltd.

Andries, P. and Czarnitzki, D. 2014. Small firm innovation performance and employee involvement. Small Business Economics, 43(1), pp. 21-38.

Angela Baron, (2011, Measuring Human Capital, Strategic HR Review, Vol. 10 Issue: 2, pp.30-35.

Ansari, S., Munir, K., and Gregg, T. 2012. Impact at the 'bottom of the pyramid': the role of social capital in capability development and community empowerment. Journal of Management Studies, 49(4), pp. 813-842.

Atherton, A. and Smallbone, D. 2010. State promotion of SME development at the local level in China - An examination of two cases. Journal of Chinese Entrepreneurship 2(3) pp. 225-241.

Atherton, A. 2008. From 'Fat Pigs' and 'Red Hats' to a 'New Social Stratum': the changing face of enterprise development policy in China. Journal of Small Business and Enterprise Development. 15(4) pp. 640-55.

Audretsch, D.B., Coad, A. and Segarra, A. 2014, Firm growth and innovation. Small Business Economics, 43(4), pp. 743-749

Autio, E. (2005), Global Entrepreneurship Monitor. Report on High Expectation Entrepreneurship, GEM, London.

Baldwin, J.R. and Johnson, J. (1995), Human Capital Development and Innovation: The Case of Training in Small and Medium Sized Firms, Statistics Canada Working Paper No. 74.

Baptista, R., Karaoz, M. and Mendonca, J. (2013), The impact of Human Capital on The Aarly

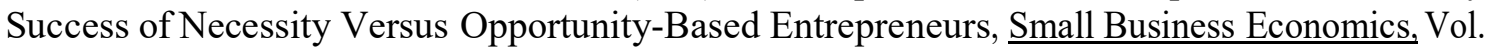
42 No. 4, pp. 831-847.

Barney, J. (1991), Firm Resources and Sustained Competitive Advantage, Journal of Management, Vol. 17 No. 1, pp. 99-120. 
Baron, RM, and Kenny, DA (1986), The Moderator-Mediator Variable Distinction in Social, Phychological Research: Conceptual, Strategic, and Satistical Consideration, Journal of Personality and Social; Phychology, Vol. 51 No.6, p11-73.

Baum, R., Locke, E. and Smith, K. (2001), A Multi-Dimensional Model of Venture Growth, Academy of Management Journal, Vol. 44 No. 2, pp. 292-303.

Baumol, W.J. (2004), Entrepreneurial Cultures and Counter Cultures, Academy of Management Learning and Education, Vol. 3 No. 3, pp. 316-326.

Baden-Fuller, C. and Haefliger, S. 2013. Business models and technological innovation. Long Range Planning, 46, pp. 419-426.

Bagno, R. B., Salerno, M. S. and da Silva, D. O. 2017. Models with graphical representation for innovation management: a literature review. R\&D Management. 47(4). 637-653.

Baptista, R., Karaoz, M. and Mendonca, J. (2013). The impact of human capital on the early success of necessity versus opportunity-based entrepreneurs. Small Business Economics, 42(4), pp. 831-847.

Bayne, L., Schepis, D. and Purchase, S. 2017. A framework for understanding strategic network performance: exploring efficiency and effectiveness at the network level. Industrial Marketing Management, 67. Pp. 1 -18.

Becker, G.S. (1964), Human Capital, University of Chicago Press, Chicago, IL.

Berrou, J.P. and Combarnous, F. .2011. The personal networks of entrepreneurs in an informal African urban economy: does the 'strength of ties' matter. Review of Social Economy, 70(1), pp. 1-30.

Birkinshaw, J.; Bouquet, C. and Barsoux, J.-L. 2011. The 5 Myths of Innovation. MIT Sloan Management. 52(2).

Bizzi, L. and Langley, A. 2012. Studying processes in and around networks. Industrial Marketing Management, 41(2), pp. 224-234.

Blumberg, B.F. and Pfann, G.A. (1999), Social Capital and The Self Employment Decision, Unpublished Manuscript, Business Investment Research Center, Maastricht University.

Boso, N., Cadogan, J. W., \& Story, V. M. 2012. Complementary effect of entrepreneurial and market orientations on export new product success under differing levels of competitive intensity and financial capital. International Business Review, 21(4), pp. 667-681.

Bouncken, R. B. 2011. Innovation by operating practices in project alliances-when size matters. British Journal of Management, 22, pp. 586-608.

Brem, A., Maier, M. and Wimschneider, C. 2016. Competitive advantage through innovation: the case of Nespresso", European Journal of Innovation Management, 19(1), pp. 133-148.

Brown, B. 2010. Why innovation matters. Research : Technology Mnagement. November-December 2010.

Brown, J.D., Earle, J.S. and Lup, D. 2005. What makes small firms grow? Finance, human capital, technical assistance, and the business environment in Romania. Economic Development and Cultural Change, 54(1), pp. 33-70.

Bustinza, O.F., Gomes, E., Vendrell-Herrero, F. and Baines, T. 2017. Product-service innovation and performance: the role of collaborative partnerships and R\&D intensity. R\&D Management. pp. $1-13$.

Calantone, R.J., Cavusgil, S.T. and Zhao, Y. (2002), Learning Orientation, Firm Innovation Capability, and Firm Performance, Industrial Marketing Management, Vol. 31 No. 6, pp. 515-524.

Cantner, U., Goethner, M. and Meder, A. (2010), Prior Knowledge and Entrepreneurial Innovative Success", Entrepreneurship and Culture, doi:10.1007/978-3-540-87910.

Chandler, N. and Hanks, Steven H. (1994). Founder Competence, The Environment, and Venture Performance. Entrepreneurship Theory and Practice. Waco: Spring. Vol. 18, Iss. 3;pg.77, 13pgs.

Cantner, U., Goethner, M. and Meder, A. (2010). Prior knowledge and entrepreneurial innovative 
success. Entrepreneurship and Culture, doi:10.1007/978-3-540-879 pp.10-25.

Capó-Vicedo, J., Mula, J., \& Capó, J. (2011). A social network-based organizational model for improving knowledge management in supply chains. Supply Chain Management: An International Journal, 16(4), pp. 284-293.

Cefis, E. and Marsili, O. (2006), Survivor: The Role of Innovation in Firms' Survival, Research Policy, Vol. 35 No. 5, pp. 626-641.

Cerne, M., Jaklic, M. dan Škerlavaj, M. (2013), "Decoupling management and technological innovations: resolving the individualism-collectivism controversy", Journal of International Management, Vol. 19 No. 2, pp. 103-117.

Cerne, M., Jaklic, M., Skerlavaj, M., Aydinlik, A. and Polat, D. (2012), "Organizational learning culture and innovativeness in Turkish firms", Journal of Management and Organization, Vol. 18 No. 2, pp. 193-219.

Chittithaworn, C., Islam, M.A., Keawchana, T. and Yusuf, D.H.M. (2011), "Factors affecting business success of small \& medium enterprises (SMEs) in Thailand", Asian Social Science, Vol. 7 No. 5, pp. 180-190.

Clauss, T. 2017. Measuring business model innovation: conceptualization, scale development, and proof of performance. R\&D Management 47 (3) pp. 385-404.

Coleman, J.S. (1988), Social Capital in The Creation of Human Capital, American Journal of Sociology, Vol. 94 No. S1, pp. 95-120.

Coleman, S. (2007), The role of Human and Fnancial Capital in The Profitability and Growth of Women-Owned Small Firms, Journal of Small Business Management, Vol. 45 No. 3, pp. 303-319.

Cosgun, V. and Dogerlioglu, O. (2012), "Critical success factors affecting e-commerce activities of small and medium enterprises", Information Technology Journal, Vol. 11 No. 12, pp. 16641667.

Cooper, A., Gimeno-Gascon, F.J. and Woo, C.Y. (1994), Initial Human Capital and Financial Capital as Predictors of New Venture Performance, Journal of Business Venturing, Vol. 9 No. 5, pp. 371-395.

Cosgun, V. and Dogerlioglu, O. (2012), "Critical success factors affecting e-commerce activities of small and medium enterprises", Information Technology Journal, Vol. 11 No. 12, pp. 16641667.

Covin, J. G. and Slevin, D. P. (1989). Strategic Management of Small Firm in Hostile and Began Environments, Strategic Management Journal, 10, 75-87.

D’Alvano, Luigi and Hidalgo, A. 2012. Innovation management techniques and development degree of innovation process in service organizations. R\&D Management 42(1). Pp. 60-72.

Damanpour, F. and Aravind, D. (2011), "Managerial innovation: conceptions, processes, and antecedents", Management and Organization Review, Vol. 8 No. 2, pp. 423-454.

Damanpour, F. (1991), Organizational Innovation: A Meta analysis of Dffects of Determinants and Moderators, Academy of Management Journal, Vol. 34 No. 3, pp. 555-590.

David, Fred R, 2011, Strategic Management Concept and Cases Thirteen Edition, New Jersey: Prentice Hall. Inc.

Dayan, M., Zacca, R., Husain, Z. and Ryan, J.C. (2016), "The effect of entrepreneurial orientation, willingness to change, and development culture on new product exploration in small enterprises", Journal of Business \& Industrial Marketing, Vol. 31 No. 5, pp. 668-683.

Donckels, R. and Frohlich, E. (1991), Are Family Businesses Really Different? European Experiences From STRATOS", Family Business Review, Vol. 4 No. 2, pp. 149-161.

Edwards, K.L. and Gordon, T.J. (1984), Characterization of Innovations Introduced on The US Market in 1982, No. SB-6050-0A-82, US Small Business Administration.

Ekopuri, D. S., Widyadari, F., \& Tamani, L. 2007. Small enterprise development policies in Indonesia. Turin: ILO Training Centre. 
Fama, E. and Miller, M. (1972), The Theory of Finance, Rinehart \& Winston, Holt, New York.

Fritsch, M. and Meschede, M. (2001), Product Innovation, Process Innovation, and Size, Review of Industrial Organization, Vol. 19 No. 3, pp. 335-350.

Galender, J. and De la Fuente, J. (2003), Internal Factors Determining a Firmś Innovative Behaviour, Research Policy, Vol. 32 No. 5, pp. 715-736.

Garrigos-Simon, F. J., \& Marques, D. P. (2004). Competitive strategies and firm performance: A study in the Spanish hospitality sector. Management Research 2(3), 251-269.

Granovetter, M.S. (1985), Economic Action and Social Structure: The Problem of Embeddedness, American Journal of Sociology, Vol. 91 No. 3, pp. 481-510

Grant, R. M. (1991). A Resource-Based Theory of Competitive Advantage: Implications for Strategy Formulation. California Management Review, Spring, 114-135..

Gündoğdu, M. Ç. (2012). Re-Thinking Entrepreneurship, Intrapreneurship, and Innovation: A Multi-Concept Perspective. Procedia - Social and Behavioral Sciences 41 (2012) 296-303.

Hall, J., Matos, S., Sheehan, L. and Silvestre, B. 2012. Entrepreneurship and innovation at the base of the pyramid: a recipe for inclusive growth or social exclusion? Journal of Management Studies. 49(4), pp. 785-812

Hamel, G. and Prahalad, C.K. (1994), Competing for the Future, Harvard Business School Press, Boston, MA.

Hausman, A. (2005), Innovativeness among Small Businesses: Theory and Propositions for Future Research, Industrial Marketing Management, Vol. 34 No. 8, pp. 773-782.

Heunks, F.J. (1998), Innovation, Creativity and Success, Small Business Economics, Vol. 10 No. 3, pp. 263-272.

Hong, J., Hou, B., Zhu, K. Marinova, D. (2018) "Exploratory innovation, exploitative innovation and employee creativity: The moderation of collectivism in Chinese context", Chinese Management Studies, Vol. 12 Issue: 2, pp.268-286.

Honig, B. (1998), What Determines Duccess? Examining the Human, Financial, and Social Capital of Jamaican Microentrepreneurs, Journal of Business Venturing, Vol. 13 No. 5, pp. 371-394.

Hsieh, M. and Tsai, K. (2007), Technological Capability, Social Capital and The Launch Strategy for Innovative Products, Industrial Marketing Management, Vol. 36 No. 4, pp. 493-502.

Huang, H-C. 2016. Entrepreneurial resources and speed of entrepreneurial success in an emerging market: the moderating effect of entrepreneurship. International Entrepreneurship Management Journal. 12, pp. 1-26.

Huang, Ju-Yu, Chou, T-C., Lee, G-G. 2010. Imitative innovation strategies: Understanding resource management of competent followers. Management Decision, 48(6) pp. 952-975.

Huggins, R., Johnston, A. and Thompson, P. (2012), "Network capital, social capital and knowledge flow: how the nature of inter-organizational networks impacts on innovation", Industry \& Innovation, Vol. 19 No. 3, pp. 203-232.

Huizingh, E.K.R.E. 2011 Open innovation: state of the art and future perspectives. Technovation, 31, pp. 2-9.

Hunt, R.A. and Ortiz-Hunt, L.L. (2017), "Entrepreneurial round tripping: the benefits of newness and smallness in multi-directional value creation”, Management Decision, Vol. 55 No. 3, pp. 491511.

Jämsä, P., Ta" htinen, J., Ryan, A. and Pallari, N. (2011), "Sustainable SMEs network utilization: the case of food enterprises", Journal of Small Business and Enterprise Development, Vol. 18 No. 1, pp. 141-156.

Jack, S., Moult, S., Anderson, A.R. and Dodd, S. (2010), “An entrepreneurial network evolving: patterns of change”, International Small Business Journal, Vol. 28 No. 4, pp. 315-337.

Jerusalem, M. A. (2009). Perancangan Industri Kreatif Bidang Benchmarking pada Queensland's Creative Industry. Prosi 2009. Vol. 4 No. 1: 380-389. 
Jussila, A., Jussila, A., Mainela, T., Mainela, T., Na" tti, S. and Na" tti, S. (2016), "Formation of strategic networks under high uncertainty of a megaproject", Journal of Business \& Industrial Marketing, Vol. 31 No. 5, pp. 575-586.

Knörr, H. 2011. From top management to entrepreneurship: women's next move? International Journal of Manpower, 32(1) pp. 99-116.

Koellinger, P. (2008), Why are some Entrepreneurs more Innovative than Others?, Small Business Economics, Vol. 31 No. 1, pp. 21-37.

Landry, R., Amara, N. and Lamari, M. (2002), Does Social Capital Determine Innovation? To what Extent?, Technological Forecasting \& Social, Vol. 69 No. 7, pp. 681-701.

Lans, T., Verstegen, J. and Mulder, M. 2011. Analysing, pursuing and networking: towards a validated three-factor framework for entrepreneurial competence from a small firm perspective. International Small Business Journal, 29(6), pp. 695-713.

Lee, K., Woo, H. and Joshi, K. (2017), "Pro-innovation culture, ambidexterity and new product development performance: polynomial regression and response surface analysis", European Management Journal, Vol. 35 No. 2, pp. 249-260.

Lee, S., Park, G., Yoon, B. and Park, J. 2010. Open innovation in SMEs-an intermediate network model. Research Policy, 39(2), pp. 290-300.

Lee, S., Park, G., Yoon, B. and Park, J. (2010), Open Innovation in SMEs-An Intermediated Network Model, Vol. 39 No. 2, pp. 290-300.

Liao, S., Hu, D., Chen, C. and Lin, Y. (2015), "Comparison of competing models and multi-group analysis of organizational culture, knowledge transfer, and innovation capabilit", Knowledge Management Research and Practice, Vol. 13 No. 3, pp. 248-260

Lightfoot, H. W., Gebauer, H. 2011. Exploring the alignment between service strategy and service innovation. Journal of Service Management, 22(5) pp. 664-683.

Luca, P. and Presutti, M. 2010. The impact of social capital on the start-ups performance growth", Journal of Small Business Management. 48(2) pp. 197-227.

Lumpkin, G.T. and Dess, G.G. (1996), Clarifying the Entrepreneurial Orientation Construct and

Mahemba, C.M. and De Bruijn, E.J. (2003), Innovation Activities by Small and Medium-Sized Manufacturing Enterprises in Tanzania, Creativity and Innovation Management, Vol. 12 No. 3, pp. 162-173.

Manikas, I. and Terry, L.A. 2010. A case study assessment of the operational performance of a multiple fresh produce distribution centre in the UK. British Food Journal 112 (6), pp. 653-667.

Manolova, T., Eunni, R. and Gyoshev, B. 2008. Institutional environments for entrepreneurship: evidence from emerging economies in Eastern Europe. Entrepreneurship Theory \& Practice, 32(1) pp. 203-18.

Martin, B.R. 2012. The evolution of science policy and innovation studies. Research Policy, 41, pp. $1219-1239$.

Martín-de Castro, G., Delgado-Verde, M., Navas-López, J. and Cruz-González, J. (2013), “The moderating role of innovation culture in the relationship between knowledge assets and product innovation", Technological Forecasting and Social Change, Vol. 80 No. 2, pp. 351-363.

Miles, R.E. and Snow, S.S. (1978), Organizational Strategy, Structure, and Process, McGraw Hill, New York, NY.

Mitchelmore, S. and Rowley, J. 2013. Entrepreneurial competencies of women entrepreneurs pursuing business growth. Journal of Small Business and Enterprise Development, 20(1) pp. $125-142$.

Mitchelmore, S. and Rowley, J. 2010. Entrepreneurial competencies: a literature review and development agenda. International Journal of Entrepreneurial Behaviour \& Research,16(2) pp. 92-111.

Mohannak, K. (2007). Innovation Networks and Capability Building in the Australian HighTechnology SMEs. European Journal of Innovation Management Vol.10(2): 236-251. 
Moretti, A. (2017), The Network Organization: A Governance Perspective on Structure, Dynamics and Performance, Palgrave Macmillan, Cham.

Moschieri, C. and Mair, J. 2011. Adapting for Innovation: Including Divestitures in the Debate. Long Range Planning 44 (2011) pp. 4-25..

Naqshbandi, M. (2016), "Managerial ties and open innovation: examining the role of absorptive capacity", Management Decision, Vol. 54 No. 9, pp. 2256-2276.

$\mathrm{Ng}, \mathrm{W}$. and Rieple, A. (2014), "Special issue on 'the role of networks in entrepreneurial performance : new answers to old questions?", International Entrepreneurship and Management Journal, Vol. 10 No. 3, pp. 447-455

Nonino, F. (2013), "The network dimensions of intra-organizational social capital", Journal of Management \& Organization, Vol. 19 No. 4, pp. 454-477.

Omri, A. and Ayadi-Frikha, M. (2014), Constructing a Mediational Model of Small Business Growth, International Entrepreuneurship an Management Journal, Vol. 10 No. 2, pp. 319-342.

Omri, A. and Frikha, M. (2014), How Small Business Fail in Tunisia?, International Journal of Economic and Accounting, Vol. 5, pp. 126-144.

Omri, A. and Frikha, M. (2012), How Entrepreneurs Identify Opportunities and Access to External Financing in Tunisian's Micro-Enterprises?, African Journal of Business Management, Vol. 6 No. 12, pp. 4635-4647.

Omri, A., Frikha, M. A., Bouraoui, M.A. 2015. An empirical investigation of factors affecting small business success. Journal of Management Development 34(9) pp. 1073-1093

Orser, B.J., Hogarth-Scott, S. and Riding, A. (2000), Performance, Firm Size and Management Problem Solving, Journal of Small Business Management, Vol. 38 No. 4, pp. $42-58$.

Parihar, P., Kher, S., Nanda, R. and Singh, S. 2013. Study on entrepreneurial competencies of women entrepreneurs in Jammu district of Jammu and Kashmir state. Economic Affairs, 58(1), pp. 4956.

Parra-Requena, G., Ruiz-Ortega, M.J. and Garcia-Villaverdea, P.M. (2013), "Social capital and effective innovation in industrial districts: dual effect of absorptive capacity", Indstry \& Innovation, Vol. 20 No. 2, pp. 157-179.

Penrose E.T. (1995) .The Theory fo The Growth of The Fimrs, New York: Weley.

Pereira, N.C., Araújo, N. and Costa, L. (2018) "A counting multidimensional innovation index for SMEs", Benchmarking: An International Journal, Vol. 25 Issue: 1, pp.2-23

Perry-Smith, J. and Mannucci, V. P. 2017. From creativity to innovation: the social network drivers of the four phases of the idea journey. Academy of Management Review, 42, pp. 53-79.

Peters, L.D., Pressey, A.D. and Johnston, W.J. (2017), "Contagion and learning in business networks", Industrial Marketing Management, Vol. 61, pp. 43-54.

Porter, M.E. (1980), Competitive Strategy: Techniques for Analyzing Industries and Competitors, Free Press, New York, NY.

Prajogo, D. I., \& McDermott, C. M. 2011. The relationship between multidimensional organizational culture and performance. International Journal of Operations \& Production Management, 31(7): $712-735$

Price, D.P., Stoica, M. and Boncella, R.J. (2013), "The relationship between innovation, knowledge, and performance in family and non-family firms: an analysis of SMEs", Journal of Innovation and Entrepreneurship, Vol. 2 No. 14, pp. 1-20

Rahman, S.A., Amran, A., Ahmad, N.H. and Taghizadeh, S. K. 2015. Supporting entrepreneurial business success at the base of pyramid through entrepreneurial competencies. Management Decision. 53(6) pp. 1203-1223.

Rip, A. 2012. The Context of Innovation Journeys. Creativity and Innovation Management. 21(2). pp. $158-170$

Ritala, P. 2012. Coopetition strategy - when is it successful? Empirical evidence on innovation and market performance. British Journal of Management, 23, pp. 307-324. 
Schumpeter, J.A. (1934), Theory of Economic Development, Harvard University Press, Cambridge.

Smith, H. L., \& Bagchi-Sen, S. (2012). The research university, entrepreneurship and regional development: Research propositions and current evidence. Entrepreneurship and Regional Development, 24, 383-404

Sohyoun, Synthia dan Shin, Sungho Lee , (2016), An Examination of firms' Strategic Orientations, Innovativeness and Performance with Large Korean Companies, Asia Pacific Journal of Innovation and Entrepreneurship, Vol. 10 Iss 1 pp. 183 - 202.

Squalli, J. and Wilson, K. (2014), “Intelligence, creativity, and innovation”, Intelligence, Vol. 46, pp. 250-257.

Stam, W., Arzlanian, S. and Elfring, T. 2014. Social capital of entrepreneurs and small firm performance: a meta-analysis of contextual and methodological moderators. Journal of Business Venturing, 29(1) pp. 152-173.

Stephen, S. (2013). Bulding an Entrepreneurial Network: The Experiences of Immigrant Entrepreneurs, Journal of Enterprinsing Cummuities: People and Places In Global, Economy, 7(3) 233-244.

Suliyanto (2011), "The effect of orientation learning on competitive advantage through innovation: study on small and medium enterprises", Business and Management Review, Vol. 1 No. 7, pp. 28-36.

Tambunan, T. 2008. SME development, economic growth, and government intervention in a developing country: the Indonesian story. Journal International Entrepreneurship, 6(147-167): 147.

Tambunan, T. 2010. The Indonesian experience with two big economic crises. Modern Economy, 1: 156-167.

Tapsell, P. and Woods, C. 2010. Social entrepreneurship and innovation: self organization in an indigenous context. Entrepreneurship and Regional Development, 22(6), pp. 535-556.

Tesluk, P.E., Farr, J.L. and Klein, S.A. (1997), Influences of Organizational Culture and Climate on Individual Creativity, Journal of Creative Behavior, Vol. 31

Thornhill, S. (2006), Knowledge, Innovation and Firm performance in High- and Low-Technology Regimes, Journal of Business Venturing, Vol. 21 No. 5, pp. 687-703.No.1, pp.27-41.

Tseng, S. (2010). The Correlation between organizational culture and knowledge conversion on corporate performance. Journal of Knowledge Management, 14(2), 269-284.

Undang-Undang No. 9 tahun 1995 , Tentang Usaha Menengah dan Kecil.

Undang-undang No. 20 Tahun 2008, Tentang Usaha Mikro, Kecil dan Menengah.

Unger, J.M., Rauch, A., Frese, M. and Rosenbusch, N. (2011), "Human capital and entrepreneurial success: a meta-analytical review", Journal of Business Venturing, Vol. 26 No. 3, pp. 341-358.

Urbach, N., Smolnik, S. and Riempp, G. 2011. Determining the improvement potentials of employee portals using a performance-based analysis. Business Process Management Journal. 175, pp. $829-845$

Valkokari, K. (2015), "Describing network dynamics in three different business nets", Scandinavian Journal of Management, Vol. 31 No. 2, pp. 219-231.

Valaei, N., Rezaei, S. and Ismail, W.K.W. (2017), "Examining learning strategies, creativity, and innovation at SMEs using fuzzy set qualitative comparative analysis and PLS path modeling", Journal of Business Research, Vol. 70, pp. 224-233.

Vega, A., Brown, D. and Chiasson, M. 2013. Open innovation and SMEs Exploring policy and the scope for improvements in university-based public programmes through a multidisciplinary lens. International Journal of Entrepreneurial Behaviour \& Research 18(4) pp. 457-476

Venkatraman, N., and V. Ramanujam (1986). Measurement of Business Performance in Strategy Research: A Comparison of Approaches, Academy of Management Review 11(4), 801-814. 
Verbees, F.J.H.M. and Meulenberg, M.T.G. (2014), "Market orientation, innovativeness, product innovation, and performance in small firms”, Journal of Small Business Management, Vol. 42 No. 2, 134-154.

Viverita dan Ariff, M. 2008. On Productivity Performance Gains of Indonesian Firm, Managerial Finance. Vol. 34 No. 9: 644-659.

Wensley, Anthony K.P. Juan Gabriel Cegarra-Navarro, Gabriel Cepeda-Carrión, Antonio Genaro Leal Millán, (2011), How entrepreneurial actions transform customer capital through time: Exploring and exploiting knowledge in an open-mindedness context, International Journal of Manpower, Vol. 32 Iss: 1 pp. $132-150$

Wirnerfelt, B. (1984), A Resources-Based View of The Firm. Strategic Management, Journal 5: pp 171-180.

World Bank (2015), Small and Medium Enterprises (SMEs). Finance: The World Bank Key Messages Bulletin, The World Bank, Washington, DC.

Zahra, S. A., and Das, S.R. 1993, Innovation Strategy and Financial Performance in Manufacturing Companies: An Empirical Study, Production and Operation Management, Vol 2 No. 1 :15-37. 